\title{
Developing Mobile Application for Land Value Capture Scheme to Finance Urban Rail Transit Projects
}

\author{
Mohammed Ali Berawi ${ }^{1,2 *}$, Nyoman Suwartha ${ }^{1}$, Agatha Vania Salim², Gunawan Sarojii2,3, \\ Mustika Sari² \\ ${ }^{1}$ Department of Civil and Environmental Engineering, Faculty of Engineering, Universitas Indonesia, \\ Kampus UI Depok, Depok 16424, Indonesia \\ ${ }^{2}$ Center for Sustainable Infrastructure Development, Faculty of Engineering, Universitas Indonesia, Kampus \\ UI Depok, Depok 16424, Indonesia \\ ${ }^{3}$ Department of Civil Engineering, Politeknik Negeri Bengkalis, Sungai Alam, Bengkalis, 28711, Indonesia
}

\begin{abstract}
Land value capture (LVC) has shown great potential in financing urban rail system infrastructure, such as transit-oriented development (TOD). However, the government of Indonesia has not tapped this potential in order to close its infrastructure financing gap. This study aims to determine the incremental rate captured through a tax-based LVC mechanism and develop a property market-based mobile application to implement the scheme, with six TOD areas in seven stations of the Mass Rapid Transit (MRT) Jakarta Phase I project as the case study. This research used literature and benchmarking studies to collect data, followed by the calculations of the transport premium, total value increment, and value capture rate for the betterment tax implementation to obtain its research objectives. The results showed that a $5.82 \%$ value capture rate could recover $53.8 \%$ of the government's initial investment for the project. Based on that figure, betterment tax rates of $0.3 \%$ and $0.1 \%$ are proposed for residential properties within the radius of $100-400 \mathrm{~m}$ and $400-700 \mathrm{~m}$ from transit stations, respectively. Meanwhile, $2.5 \%$ and $2.4 \%$ tax rates are proposed for commercial properties within the radius of 0-300 $\mathrm{m}$ and 300-600 $\mathrm{m}$, respectively. Furthermore, the activity workflow for a mobile application in which the government can issue tax invoices and taxpayers can make payments is also proposed to facilitate the implementation of LVC as an alternative source to finance TOD projects.
\end{abstract}

Keywords: Betterment tax; Land value capture; Mobile application; Transit-oriented development

\section{Introduction}

Cities in some developing countries are experiencing staggering growth driven by rapid urbanization (Kumara and Gopiprasad, 2019). However, cities' rapid growth is frequently accompanied by negative externalities, such as traffic congestion, pollution, and urban sprawl (Albalate and Fageda, 2019). To tackle those issues, many countries are investing in public transit infrastructure that could be further developed to form a compact, mixed-use, and pedestrian-friendly area organized around a transit station, known as Transit-Oriented Development (TOD). 
Indonesia has started developing its infrastructure in order to stimulate its national economic growth (Latief et al., 2016; Hansen et al., 2018). The prioritized projects outlined in Indonesia's National Strategic Projects are urban transit infrastructure, which includes the Mass Rapid Transit (MRT) Jakarta project, Light Rail Transit (LRT) Jabodebek project, and LRT Palembang project (Maimunah and Kaneko, 2016; Farda and Lubis, 2018; Sulaeman and Haryadi, 2018). However, the Indonesian government experiences a fiscal constraint as there is a $63 \%$ infrastructure-funding gap in meeting the total investment required. Therefore, an alternative funding source is needed so that the burden on the general taxations or fare-box revenue would not increase (Gunawan et al., 2020).

Land value capture (LVC) is an effort to monetize infrastructure capital investments to capitalize on land value (Suzuki et al., 2015; Huston and Lahbash, 2018) that has been widely considered one of the financing sources for the investment of infrastructure and urban development. It relies on the principle that all of the benefits from the added value of transit development must contribute to the cost of transit (Roukouni et al., 2018).

Abiad et al. (2019) has reported the difference between the land value uplift in Jakarta capital city areas. Land value uplift in the Dukuh Atas area serviced by the rail transit system reached $38.4 \%$ between 2015 and 2018, and the Harmoni area with no rail transit system service only had $14.3 \%$. These figures implied that a transit-serviced area receives a more significant uplift in terms of land value. Moreover, Indonesia's tax-to-GDP ratio of $11.9 \%$ in 2018 was still under-collected compared to Malaysia $(12.5 \%)$, Singapore $(13.2 \%)$, the Philippines (18.2\%), and Thailand (17.5\%) (OECD, 2020). Hence, this research focused on tax-based value capture mechanisms for TOD projects in Jakarta as the capital city of Indonesia.

Previous studies regarding LVC mainly focused only on measuring the increase of land value as the impacts of the accessibility benefits gained by landowners and private sectors (Pagliara and Papa, 2011; McIntosh et al., 2014; Zhang and Xu, 2017). Therefore, this research attempts to determine a tax rate aligned with LVC scheme principles and propose a mobile application to implement the scheme to finance the initial investment to develop rail transit infrastructure, with the MRT Jakarta Phase I project as the case study. The findings of this study are expected to contribute insight for discussion among policymakers, practitioners, and researchers regarding LVC as a source of project finance for urban transit development.

\section{Methods}

To reach its objective, this study adopted the method that Zhang and $\mathrm{Xu}$ (2017) developed to estimate the potential of value capture in Wuhan (China). It did this by calculating the value increments caused by the provision of Wuhan MRT Line 2 transit services and simulating the captured value gained from a considered $0.5 \%$ tax on the properties' value increments. However, the reasoning behind the $0.5 \%$ value capture rate implemented in that study was not provided; hence, this study aimed to determine the basis of the value capture rate proposed for urban rail transit projects with MRT Jakarta Phase 1 development as the case study.

At the time this study was conducted (2018-2019), Perseroan Terbatas MRT Jakarta (PT MRTJ) as the developer and operator of MRT Jakarta project had prepared a master plan proposal for TOD area developments at seven out of 13 stations in the Phase 1 development, which consists of the Lebak Bulus Station, Fatmawati Station, Blok M Station, ASEAN Station, Istora Station, Senayan Station, and Dukuh Atas Station. The initial investment of these stations amounted to $53.8 \%$ of the total investment of MRT Jakarta (KPPIP, 2019). There were six TOD areas proposed in the master plan, including TOD Lebak 
Bulus, TOD Fatmawati, TOD Blok M-ASEAN, TOD Istora, TOD Senayan, and TOD Dukuh Atas.

This research occurred in two stages in order to determine the incremental rate captured and the potential revenue generated through a tax-based LVC mechanism, as well as develop a mobile application for both the government and the taxpayers to use in the scheme implementation. In the first stage, literature and benchmark studies were conducted to collect data, including: (1) premium prediction around residential and commercial properties with sources from Wuhan (Zhang and $\mathrm{Xu}, 2017$ ), Perth (McIntosh et al., 2014), and Jakarta (Berawi et al., 2019b; Berawi et al., 2020b); (2) average residential selling price per square meter (Berawi et al., 2020a; Salanto and Gobi, 2020); (3) average commercial selling price per square meter (Berawi et al., 2019b; Berawi et al., 2020a); (4) targeted land-use development around transit stations, and (5) targeted Gross Floor Area (GFA) (PT MRT Jakarta, 2019). These data were then processed to estimate the land area of each TOD project, Floor Area Ratio (FAR), and GFA, and calculate the Transport Premium (TP), total value increment, and value capture rate for the betterment tax implementation.

The estimations and calculations were conducted by following the steps below.

1. Estimating land area for each residential and commercial parcel

The land area for each parcel was estimated based on the proposed land use and zoning of the TOD areas near the transit stations. The results were then tabulated into a table containing the parcels' code, land area, property type, and the radius segment relative to the transit.

2. Estimating FAR

FAR for the commercial and residential properties in each TOD area was estimated using these equations:

$$
\begin{aligned}
F A R_{\text {commercial }} & =\frac{\text { Targeted total } G F A_{\text {commercial }}}{\text { Total land area }} \text { commercial } \\
F A R_{\text {residential }} & =\frac{\text { Targeted total } G F A_{\text {residential }}}{\text { Total land area } a_{\text {residential }}}
\end{aligned}
$$

3. Estimating GFA

The GFA for each catchment area segment was calculated by multiplying each land area in each segment by the estimated FAR. Furthermore, the commercial land area was multiplied by the FAR for commercial properties in the TOD area. The same was also used for residential properties.

$$
G F A=\text { Land area } \times \text { estimated FAR }
$$

4. Calculating TP and total value increment

Transport premium is a benefit capitalized by property owners located close to transportation access and is calculated by multiplying the coefficient of distance variables (DV) resulting from the Hedonic Price Modelling (HPM) and the average selling property prices per square meter (see Equation 4). The DV coefficients for residential properties were obtained from Zhang and Xu (2017) and from Berawi et al. (2019b) for commercial properties. The total increment was calculated by multiplying the GFA and the TP for each catchment area's properties, as shown in Equation 5.

$$
\begin{aligned}
& T P=D V \text { Coeficient } \times \text { Avg.price } / \text { sqm } \\
& \text { Total Increment }=\sum_{0-100}^{900-1000} \mathrm{GFA} \times \mathrm{TP}
\end{aligned}
$$

5. Calculating the value capture rate (\%)

$$
V C(\%)=\frac{53.8 \% \times \text { MRTJ's total investment }}{\text { Total increment }}
$$


A benchmarking study of existing property market-based mobile applications was conducted in the second stage in order to define the activities carried out in the proposed mobile application and then develop the activity workflows. Lastly, in-depth interviews with experts occurred to strengthen and validate the research output. The framework of the research can be seen in Figure 1.

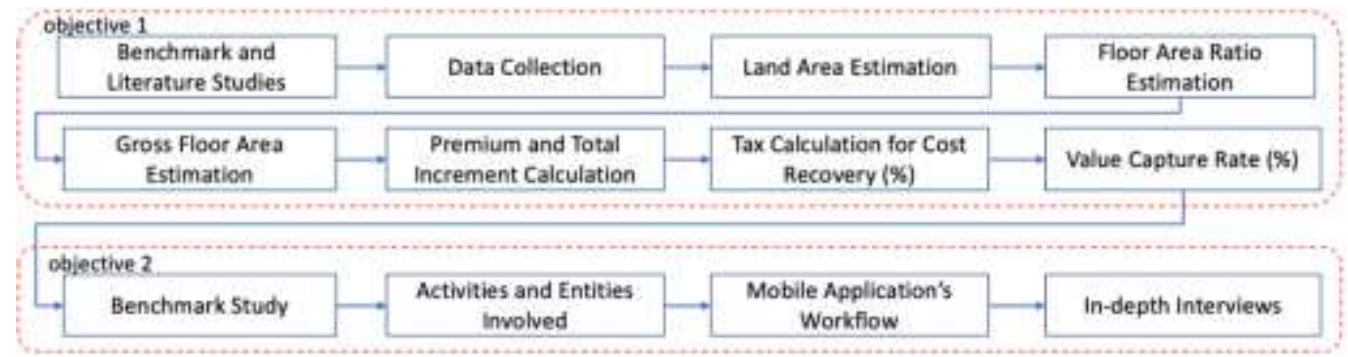

Figure 1 Research framework

\section{Results and Discussion}

\subsection{Determining Value Capture Rate for Betterment Tax Implementation}

The total increment calculation was based on the GFA of each property type in the investigated TOD areas, where a higher GFA would result in a higher increment. According to Berawi et al. (2019a), a minimum FAR of 6.57 is necessary for TOD development in Indonesia in order to conform with the density characteristics as one of the TOD principles. In retrospect, some of the planned commercial developments surrounding the MRT Jakarta stations already fulfilled the required FAR, such as Istora, Senayan, and Dukuh Atas stations. The minimum FAR was only fulfilled for the residential properties in the planned development around the Dukuh Atas station. However, some residential properties are still far below the minimum FAR suggested (see Table 1).

Table 1 Land area, FAR, and GFA for each type of property in the TOD areas

\begin{tabular}{|c|c|c|c|c|c|c|c|}
\hline \multirow[b]{2}{*}{$\begin{array}{c}\text { TOD } \\
\text { Location }\end{array}$} & \multirow[b]{2}{*}{ Radius (m) } & \multicolumn{3}{|c|}{ Residential } & \multicolumn{3}{|c|}{ Commercial } \\
\hline & & $\begin{array}{c}\text { Land Area } \\
\left(\mathrm{m}^{2}\right)\end{array}$ & FAR & $\mathrm{GFA}\left(\mathrm{m}^{2}\right)$ & Land Area $\left(\mathrm{m}^{2}\right)$ & FAR & $\mathrm{GFA}\left(\mathrm{m}^{2}\right)$ \\
\hline \multirow{8}{*}{$\begin{array}{l}\text { Lebak Bulus } \\
\text { Station }\end{array}$} & $0-100$ & - & \multirow{7}{*}{5} & & 791.14 & \multirow{7}{*}{5.7} & $4,528.56$ \\
\hline & $100-200$ & $14,781.92$ & & $73,803.77$ & $37,210.85$ & & $212,997.29$ \\
\hline & $200-300$ & $23,551.27$ & & $117,587.71$ & $10,608.28$ & & $60,722.48$ \\
\hline & $300-400$ & $8,658.63$ & & $43,231.12$ & $32,724.19$ & & $187,315.36$ \\
\hline & $400-500$ & $15,145.88$ & & $75,620.92$ & $33,418.96$ & & $191,292.25$ \\
\hline & $500-600$ & $20,648.24$ & & $103,093.35$ & $4,715.37$ & & $26,991.05$ \\
\hline & $600-700$ & $8,765.38$ & & $43,764.13$ & - & & - \\
\hline & Total & $91,551.32$ & & $457,101.00$ & $119,468.78$ & & $683,847.00$ \\
\hline \multirow{6}{*}{$\begin{array}{l}\text { Fatmawati } \\
\text { Station }\end{array}$} & $0-100$ & - & \multirow{6}{*}{1.7} & - & $19,000.55$ & \multirow{6}{*}{4.3} & $81,338.60$ \\
\hline & $100-200$ & $42,451.06$ & & $70,604.56$ & $26,318.71$ & & $112,666.57$ \\
\hline & $200-300$ & $70,301.11$ & & $116,924.76$ & $25,787.32$ & & $110,391.76$ \\
\hline & $300-400$ & $69,007.98$ & & $114,774.01$ & $36,760.54$ & & $157,366.53$ \\
\hline & $400-500$ & $33,569.50$ & & $55,832.77$ & 7,839.83 & & $33,561.16$ \\
\hline & $500-600$ & - & & - & $11,230.79$ & & $48,077.39$ \\
\hline Total & & $215,329.65$ & & $358,136.10$ & $126,937.73$ & & $543,402.00$ \\
\hline \multirow{6}{*}{$\begin{array}{l}\text { Blok M- } \\
\text { ASEAN } \\
\text { Station }\end{array}$} & $0-100$ & $53,945.36$ & \multirow{6}{*}{2.7} & $148,024.41$ & $145,415.53$ & \multirow{6}{*}{3.5} & $502,654.84$ \\
\hline & $100-200$ & $14,594.95$ & & $40,048.10$ & $40,862.63$ & & $141,249.00$ \\
\hline & $200-300$ & $63,321.34$ & & $173,751.82$ & $181,603.48$ & & $627,744.99$ \\
\hline & $300-400$ & $101,816.59$ & & $279,381.58$ & - & & - \\
\hline & $400-500$ & - & & - & $49,745.05$ & & $171,952.67$ \\
\hline & $500-600$ & $16,615.80$ & & $45,593.23$ & $14,062.49$ & & $48,609.51$ \\
\hline Total & & $250,294.04$ & & $686,799.13$ & $431,689.17$ & & $1,492,211.00$ \\
\hline \multirow{3}{*}{$\begin{array}{l}\text { Istora } \\
\text { Station }\end{array}$} & $0-100$ & - & \multirow{3}{*}{4.24} & - & $33,874.04$ & \multirow{3}{*}{6.86} & $232,427.01$ \\
\hline & $100-200$ & - & & - & $164,839.63$ & & $1,131,048.39$ \\
\hline & $200-300$ & $20,656.33$ & & $87,662.68$ & $18,280.18$ & & $125,429.63$ \\
\hline
\end{tabular}


to Finance Urban Rail Transit Projects

\begin{tabular}{|c|c|c|c|c|c|c|c|}
\hline \multirow{6}{*}{$\begin{array}{c}\text { TOD } \\
\text { Location }\end{array}$} & \multirow{3}{*}{$\frac{\text { Radius }(\mathrm{m})}{300-400}$} & \multicolumn{3}{|c|}{ Residential } & \multicolumn{3}{|c|}{ Commercial } \\
\hline & & $\begin{array}{c}\text { Land Area } \\
\left(\mathrm{m}^{2}\right)\end{array}$ & FAR & $\mathrm{GFA}\left(\mathrm{m}^{2}\right)$ & Land Area $\left(\mathrm{m}^{2}\right)$ & FAR & $\mathrm{GFA}\left(\mathrm{m}^{2}\right)$ \\
\hline & & - & & - & $32,880.86$ & & $225,612.30$ \\
\hline & 400-500 & $21,830.23$ & & $92,644.55$ & $61,532.50$ & & $422,205.71$ \\
\hline & $500-600$ & & & & $13,739.48$ & & $94,273.52$ \\
\hline & $600-700$ & & & & $18,287.39$ & & $125,479.09$ \\
\hline & Total & $42,486.56$ & & $180,307.22$ & $343,434.08$ & & $2,356,475.65$ \\
\hline \multirow{7}{*}{$\begin{array}{l}\text { Senayan } \\
\text { Station }\end{array}$} & $0-100$ & - & & - & $67,374.66$ & & $462,291.78$ \\
\hline & $100-200$ & - & & - & $20,554.08$ & & $141,031.96$ \\
\hline & $200-300$ & $109,484.72$ & & $405,763.80$ & $132,239.33$ & & $907,361.20$ \\
\hline & $300-400$ & $11,108.77$ & 3.71 & $41,170.46$ & $64,527.68$ & 6.86 & $442,757.20$ \\
\hline & $400-500$ & - & & - & - & & - \\
\hline & $500-600$ & - & & - & - & & - \\
\hline & $600-700$ & - & & - & $27,813.16$ & & $190,840.21$ \\
\hline \multicolumn{2}{|c|}{ Total } & $120,593.49$ & & $446,934.27$ & $312,508.91$ & & $2,144,282.35$ \\
\hline \multirow{10}{*}{$\begin{array}{l}\text { Dukuh Atas } \\
\text { Station }\end{array}$} & $0-100$ & - & \multirow{9}{*}{8.84} & - & $12,753.71$ & \multirow{9}{*}{7.17} & $91,432.74$ \\
\hline & $100-200$ & - & & - & $42,011.12$ & & $301,182.37$ \\
\hline & $200-300$ & $25,583.31$ & & $226,172.68$ & $71,233.86$ & & $510,683.43$ \\
\hline & $300-400$ & $45,565.54$ & & $402,828.29$ & $37,701.27$ & & $270,284.63$ \\
\hline & $400-500$ & $54,028.53$ & & $477,646.44$ & $45,939.08$ & & $329,342.35$ \\
\hline & $500-600$ & $51,987.49$ & & $459,602.36$ & $9,339.03$ & & $66,952.56$ \\
\hline & $600-700$ & $10,532.19$ & & $93,111.27$ & $112,746.44$ & & $808,291.75$ \\
\hline & $700-800$ & $14,473.81$ & & $127,957.62$ & $7,085.31$ & & $50,795.38$ \\
\hline & 800-900 & - & & - & $102,193.25$ & & $732,634.79$ \\
\hline & Total & $202,170.87$ & & $1,787,318.65$ & $441,003.07$ & & $3,161,600.00$ \\
\hline
\end{tabular}

The average asking prices per square meter for residential properties in South Jakarta

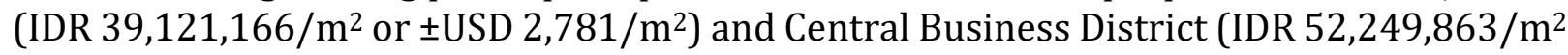
or \pm USD $3,714 / \mathrm{m}^{2}$ ) were used to calculate the price premium. Selling price data that was collected in a study Berawi et al. (2019b) conducted were used and further classified into several groups of administrative regions to determine the commercial properties' average

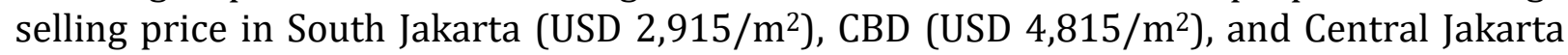
(USD 2,826/ $\mathrm{m}^{2}$ ).

Calculating the price premiums in each area and then multiplying them by the GFA shown in Table 1 resulted in the potential increment in each TOD area. The total increment that property owners can accrue due to the accessibility benefit could approximately reach IDR 157.2 trillion (USD 11,180.18 million). Table 2 shows the details of the value increment for each TOD area.

Table 2 Total value increment

\begin{tabular}{lrr}
\hline \multirow{2}{*}{ TOD Area } & \multicolumn{2}{c}{ Increment (million USD) } \\
\cline { 2 - 3 } & Residential Property & Commercial Property \\
\hline TOD Lebak Bulus & 30.23 & 666.90 \\
TOD Fatmawati & 15.96 & 533.72 \\
TOD Blok M-ASEAN & 18.89 & $1,470.83$ \\
TOD Istora & 17.53 & $3,636.57$ \\
TOD Senayan & 56.91 & $3,199.69$ \\
TOD Dukuh Atas & 13.68 & $1,519.25$ \\
\hline Sub-Total & 153.21 & $11,026.97$ \\
\hline Total & & $11,180.18$ \\
\hline
\end{tabular}

With the total investment of IDR 17 trillion (USD 1.21 billion) for the initial investment of seven MRT stations and a total increment of IDR 157.27 trillion (USD 11,180.18 million), the percentage of value capture rate needed to cover the investment cost is as follows:

$$
V C(\%)=\frac{53.8 \% \times 1,209.45 \text { million }}{\text { USD } 11,180.18 \text { million }}=5.82 \%
$$


Without any significant changes in the current taxation, the property owners would gain all of the predicted windfalls. However, the government could already cover $53.8 \%$ of the total investment made for seven stations in the MRT Jakarta Phase I by capturing only $5.82 \%$ of the estimated increment. This finding can be the basis for the government to implement the value capture rate. The tax rates resulting from multiplying the premium coefficient and the value capture rate $(5.82 \%)$ can be seen in Table 3 . The proposed tax mechanism is similar to the zonal value capture charges that Transport for London proposed (TfL \& GLA, 2017), in which the payment is made one time when the property transaction occurs.

Table 3 Tax rate

\begin{tabular}{lcc}
\hline Distance Ring $(\mathrm{m})$ & Residential & Commercial \\
\hline Ring 0-100 & & $2.5 \%$ \\
Ring 100-200 & $0.3 \%$ & $2.5 \%$ \\
Ring 200-300 & $0.3 \%$ & $2.5 \%$ \\
Ring 300-400 & $0.3 \%$ & $2.4 \%$ \\
Ring 400-500 & $0.1 \%$ & $2.4 \%$ \\
Ring 500-600 & $0.1 \%$ & $2.4 \%$ \\
Ring 600-700 & $0.1 \%$ & \\
\hline
\end{tabular}

\subsection{Developing Mobile Application for LVC Tax Scheme Implementation}

A benchmark study was conducted on some existing mobile applications providing tax payment services, including e-commerce, Annual Tax Return e-filling, and tax applications. The results showed that there are several necessary steps in the mobile application to facilitate paying land value capture taxes allocated to help finance the provision of infrastructure or supporting facilities in the TOD area (see Table 4).

Table 4 The activity steps carried out contained in the LVC mobile application

\begin{tabular}{cll}
\hline No. & \multicolumn{1}{c}{ Steps } & \multicolumn{1}{c}{ Description } \\
\hline 1. & $\begin{array}{l}\text { Detailed entry of the } \\
\text { property offered }\end{array}$ & $\begin{array}{l}\text { The seller or developer manually enters details regarding the offered property, used as } \\
\text { the basis for land value capture tax. }\end{array}$ \\
\hline 2. & $\begin{array}{l}\text { Seller's document } \\
\text { upload }\end{array}$ & $\begin{array}{l}\text { After inputting the details of the offered property, the sellers are asked to upload } \\
\text { documents related to property ownership and rights. This is intended to prevent fraud } \\
\text { and ensure the credibility of both the seller and the property offered. }\end{array}$ \\
\hline 3. & $\begin{array}{l}\text { Seller's document } \\
\text { verification }\end{array}$ & $\begin{array}{l}\text { The verification is conducted by checking the information contained in these } \\
\text { documents and comparing it with the database owned by the relevant government } \\
\text { institutions. }\end{array}$ \\
\hline 4. & Booking fee payment & $\begin{array}{l}\text { The booking fee payment process performed after the documents the seller and buyer } \\
\text { uploaded, such as ID cards and Tax ID numbers, are verified. }\end{array}$ \\
\hline 5. & LVC tax bill payment & $\begin{array}{l}\text { The app facilitates bill payment with several payment methods, such as debit card, } \\
\text { credit card, or a virtual account. }\end{array}$ \\
\hline
\end{tabular}

The property details inputted into the application in the first step are used to calculate the LVC tax to be paid. If the property is within $100 \mathrm{~m}-400 \mathrm{~m}$ from the nearest station, the buyer needs to pay $0.3 \%$ of the listing price. The tax levy is $0.1 \%$ of the listing price for property located $401 \mathrm{~m}-700 \mathrm{~m}$ from the nearest station. However, if it is in these two distance categories, the buyer is exempted from value capture tax. This tax rate calculation will be the input for the tax bill the government issued when the property rental transaction was completed. Nevertheless, the seller needs to upload the documents regarding the ownership and rights beforehand to be verified (see Figure 2).

The payment process starts with the buyer choosing the payment method; either by debit/credit card or transfer to a virtual account (VA). If the buyer decides to use a debit/credit card, the card information inputted will go through a payment gateway to 
ensure the security of the user's data, which will then be relayed to the concerned bank to verify the information's validity.

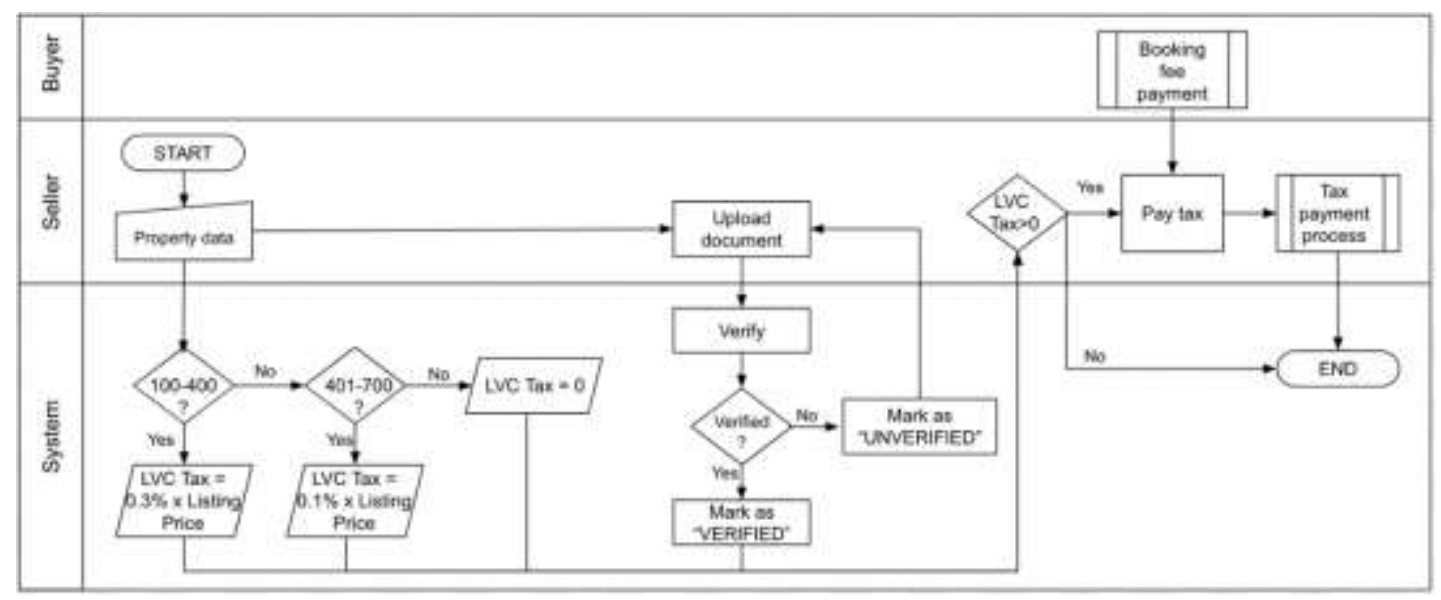

Figure 2 Workflow diagram of seller's and buyer's activities for LVC tax payment process

On the other hand, to make transactions via a VA, the buyer must transfer the agreed amount to the VA number that the bank generated. The bank will confirm and provide proof of payment if the transaction is successful (see Figure 3).

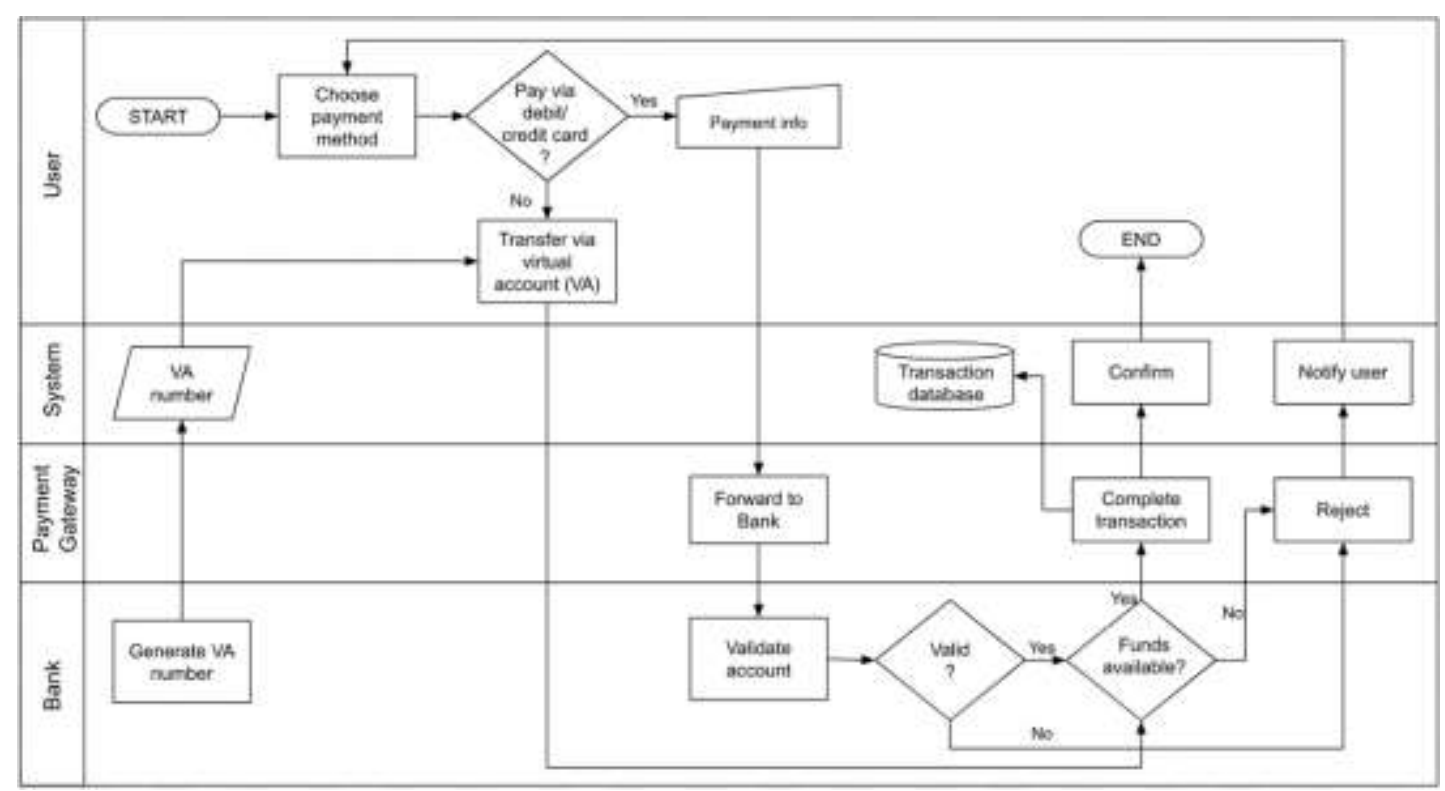

Figure 3 Workflow diagram for the LVC tax payment process in the mobile application

Experts from the mobile application development field were then consulted via indepth interviews regarding the proposed mobile application. Based on these interviews, the entities and the workflows defined are in line with the application's programming flow. However, some improvements are needed, particularly regarding the legal entity that manages this application. Its cooperation with the government also needs to be detailed since it requires government databases to verify both sellers' and buyers' documents. The user interface of the proposed mobile application can be seen in Figure 4. 


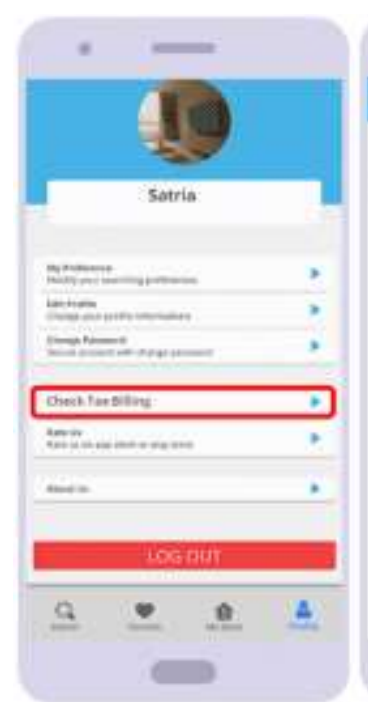

(a)

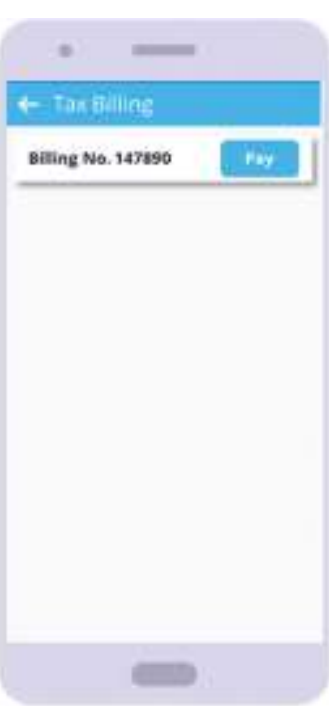

(b)

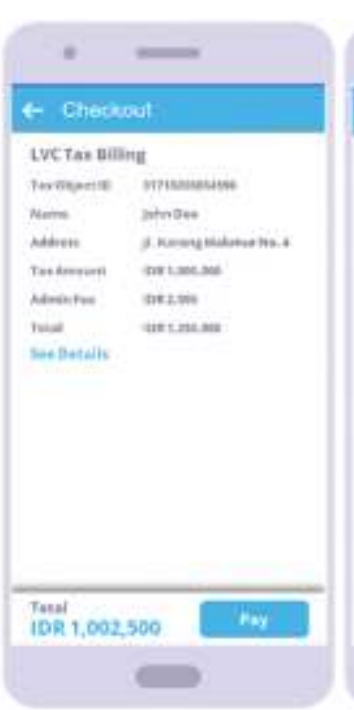

(c)

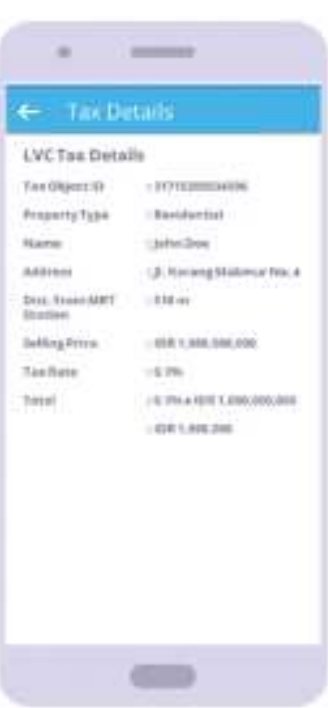

(d)

Figure 4 User interface of the proposed LVC mobile application: (a) user profile; (b) list of tax billings; (c) tax billing payment; and (d) LVC tax calculation details

Figure 4 illustrates the LVC tax payment process and shows that the property sellers could check for the tax billing through the Profile feature in the application. It would only show up on the Tax Billing feature if the property transaction has been carried out and the relevant government agency has been notified. The seller could then see the details of the tax billing, which shows the LVC tax rate corresponding to their property type and the distance between the property and the MRT stations. After checking the details, the property owners could pay for their tax billing and choose the preferred payment method available.

The mobile application workflows could simplify the conventional administrative process, in which payers were manually identified and the issued tax payment notifications were sent by post. By utilizing the proposed mobile application for betterment tax implementation, government could automatically identify taxpayers, calculate their respective tax billings, and send payment notifications of the issued tax billing through the mobile application. Moreover, it also provides a wide variety of payment methods for taxpayers, thereby increasing payment flexibility and ease of transaction.

\section{Conclusions}

The LVC can be used as an alternative source to finance the initial investment of public infrastructure, such as TOD projects. Therefore, this study aimed to determine the tax rate for the betterment tax mechanism aligned with the principles of LVC. This study's findings showed that, by capturing $5.82 \%$ of the projected increment capitalized by the property owners once they sell or lease their properties, the government could recover $53.8 \%$ of the investment costs required to develop seven stations of the MRT Jakarta Phase I project. Though the exact taxation rate calculated in this study might only be appropriate for Jakarta, considering that the land value uplift might vary across different locations worldwide, the methodology used in this study could serve as a basis for reinforcing a reasonable tax rate, which the municipal or local government in other cities across the globe could justify.

Furthermore, the proposed mobile application workflows show that the application enables the government to issue a tax bill once they have been notified that the property sale and leasing transactions were carried out. The buyer can pay the tax invoice through 
the payment gateway provided in the application, thereby supporting the implementation of the LVC mechanism.

This paper encourages future studies to investigate further regarding the implementation and benefits of other LVC mechanisms, such as Tax Increment Financing (TIF), Development Rights Auction, and other institutional schemes specializing in LVC in TOD projects.

\section{Acknowledgements}

This research was funded by the Ministry of Research and Technology, Republic of Indonesia (NKB-034/UN2.RST/HKP.05.00/2021).

\section{References}

Abiad, A., Farrin, K., Hale, C., 2019. Sustaining Transit Investment in Asia's Cities: A Beneficiary-Funding and Land Value Capture Perspective. Asian Development Bank

Albalate, D., Fageda, X., 2019. Congestion, Road Safety, and the Effectiveness of Public Policies in Urban Areas. Sustainability, Volume 11(18), pp. 1-21

Berawi, M.A., Aprianti, L., Saroji, G., Sari, M., Miraj, P., Kim, A.A., 2020a. Land Value Capture Modeling in Residential Area using Big Data Approach Method. Engineering Journal, Volume 24(4), pp. 249-259

Berawi, M.A., Darmawan, A., Gunawan, Miraj, P., Rahman, H.A., 2020b. Land Value Capture: Defining Crucial Variables Difference-In-Differences Model for Residential Properties Surrounding MRT Jakarta Stage I. Evergreen, Volume 7(2), pp. 253-261

Berawi, M.A., Ibrahim, B.E., Gunawan, Miraj, P., 2019a. Developing a Conceptual Design of Transit-Oriented Development to Improve Urban Land Use Planning. Journal of Design and Built Environment, Volume 19(1), pp. 40-48

Berawi, M.A., Suwartha, N., Salsabila, F., Gunawan, Miraj, P., Woodhead, R., 2019b. Land Value Capture Modeling in Commercial and Office Areas using a Big Data Approach. International Journal of Technology, Volume 10(6), pp. 1150-1156

Farda, M., Lubis, H., 2018. Transportation System Development and Challenge in Jakarta Metropolitan Area, Indonesia. International Journal of Sustainable Transportation Technology, Volume 1(2), pp. 42-50

Gunawan., Berawi, M.A., Sari, M., 2020. Optimizing Property Income in Transit Oriented Development: A Case Study of Jakarta TOD. Civil Engineering and Architecture, Volume 8(2), pp. 136-143

Hansen, S., Too, E., Le, T., 2018. Lessons Learned from a Cancelled Urban Transport Project in a Developing Country: The Importance of the Front-End Planning Phase. International Journal of Technology, Volume 9(5), pp. 898-909

Huston, S., Lahbash, E., 2018. Land Value Capture and Tax Increment Financing: Overview and Considerations for Sustainable Urban Investment. SSRN Electronic Journal, Volume 2(3), pp. 1-9

KPPIP, 2019. MRT Jakarta (North-South Corridor). Available Online at https://kppip.go.id/en/priority-projects/public-transportation/mrt-jakarta-northsouth-corridor/

Kumara, H., Gopiprasad, S., 2019. Rapid Urbanization and Infrastructure Financing for Mega Cities: Indian and Chinese Experiences. Institute of Town Planners, India Journal, pp. 63-77

Latief, Y., Berawi, M.A., Rarasati, A.D., Supriadi, L.S., Boy Berawi, A.R., Hayuningtiyas, I.S., 2016. Mapping Priorities for the Development of the Transportation Infrastructure in 
the Provincial Capitals of Indonesia. International Journal of Technology, Volume 7(4), pp. 544-552

Maimunah, S., Kaneko, S., 2016. MRT As Climate Policy in Urban Transportation. In: S. Kaneko, M. Kawanishi (eds.), Climate Change Policies and Challenges in Indonesia. Springer, Japan, pp. 243-264

McIntosh, J., Trubka, R., Newman, P., 2014. Can Value Capture Work in a Car Dependent City? Willingness to Pay for Transit Access in Perth, Western Australia. Transportation Research Part A: Policy and Practice, Volume 67, pp. 320-339

OECD, 2020. Revenue Statistics in Asian and Pacific Economies 2020. OECD Publishing. Available Online at https://doi.org/10.1787/8b682cbe-en

Pagliara, F., Papa, E., 2011. Urban Rail Systems Investments: An Analysis of the Impacts on Property Values and Residents' Location. Journal of Transport Geography, Volume 19(2), pp. 200-211

PT MRT Jakarta, 2019. Proposal of MRT Jakarta's TOD Area Development Master Plan (unpublished)

Roukouni, A., Macharis, C., Basbas, S., Stephanis, B., Mintsis, G., 2018. Financing Urban Transportation Infrastructure in a Multi-Actors Environment: The Role of Value Capture. European Transport Research Review, Volume 10(14), pp. 1-19

Salanto, F., Gobi, R., 2020. Colliers Quarterly Jakarta Apartment and Expat Housing Q4 2019 Report. Available Online at https://www.colliers.com/en-id/research/colliersquarterly-property-market-report-q4-2019-jakarta-apartment

Sulaeman, A.R., Haryadi, S., 2018. Traffic Engineering and Grade of Service of Passenger Flow in LRT Palembang. In: Proceeding of $20184^{\text {th }}$ International Conference on Wireless and Telematics, ICWT, pp. 1-6

Suzuki, H., Murakami, J., Hong, Y.-H., Tamayose, B., 2015. Theory of Land Value Capture and Its Instruments. In: Financing Transit-Oriented Development with Land Values: Adapting Land Value Capture in Developing Countries, Suzuki, H., Murakami, J., Hong, Y.-H., Tamayose, B. (eds.), The World Bank

TfL, GLA., 2017. Land Value Capture, Final Report (Issue February). Available Online at https://www.london.gov.uk/sites/default/files/land_value_capture_report_transport for_london.pdf

Zhang, M., Xu, T., 2017. Uncovering the Potential for Value Capture from Rail Transit Services. Journal of Urban Planning and Development, Volume 143(3), https://doi.org/10.1061/(ASCE)UP.1943-5444.0000383 